\title{
Revisiting Computer-Assisted Language Teaching: What Else Do Tertiary-Level EFL Teachers Need to Know?
}

\author{
https://doi.org/10.3991/ijet.v16i15.21815 \\ Xiaodong Zhang \\ Beijing Foreign Studies University, China \\ zxdman588@bfsu.edu.cn
}

\begin{abstract}
Computer-assisted language teaching (CALT) is widely used in teaching English as a foreign language (EFL) at the tertiary level. As illustrated by existing research, the value of CALT lies in its leveraging of technological affordances (e.g., multimodal resources or interactive spaces) to motivate students' interest in learning. However, beyond the technological level, CALT tends to treat language (i.e., vocabulary and grammar) separately from content (i.e., the meaning of a discourse). This means that to further improve CALT in the EFL context, students' understanding of the relationship between language and content, which contributes to their success in literacy activities, must be fostered pedagogically. Thus, this paper introduces systemic functional linguistics and argues for its use as a complementary tool for improving students' engagement in CALT. It also offers recommended practices for teachers in this regard.
\end{abstract}

Keywords - CALT, integration of content and language, English language teaching, literacy activities, systemic functional linguistics

\section{Introduction}

Computer-assisted language teaching (CALT) features the use of computers and related resources, including the Internet and web-based learning platforms or applications in the process of language teaching [1]. CALT has been a popular addition to the traditional tertiary-level English as a foreign language (EFL) classroom [2], [3]. Research has demonstrated its power in facilitating tertiary-level EFL teaching [2], [3], [4]. Its primary value is embodied in the following dimensions. First, it promotes students' interest in knowledge building (e.g., grammar/lexicon learning or the comprehension of textual content) inside and outside the class by offering multimodal learning (e.g., aural and visual resources, digital texts) [5],[6]. Second, it also complements students' in-class knowledge building by creating diverse channels of interaction and collaboration between the students or between the students and their teacher (e.g., peer assistance provided online, teachers' web-based feedback on students' learning) without constraints on time and place [4], [7]. Third, it enhances students' autonomous learning by providing them with a flexible after-class learning platform, such as independent learning online [8], [9]. Overall, the use of CALT has been found to be instrumental in students' language learning based on its technological function. It appears that CALT is 
superior to traditional language learning, which features teacher-student lectures and takes place only in the classroom [4].

Nevertheless, CALT needs to be further developed, as this technology-enhanced teaching still cannot meet the complex demands of tertiary-level EFL teaching. Indeed, effective literacy activities require students to uncover the close relationship between language and content in discourse deconstruction (e.g., reading) or represent the relationship between the two (e.g., writing) [10], [11]. This means that tertiary-level EFL students need to appreciate the content of a discourse and how linguistic resources are used to achieve discursive content [10]. However, this important dimension of tertiarylevel EFL teaching is not well highlighted in the currently practiced version of CALT. It has been observed that the current CALT in tertiary-level EFL classrooms to be focused either on the learning of language itself (e.g., grammar, vocabulary) or the general deconstruction or construction of discourses (e.g., using general comprehension questions to promote thinking in writing or reading) [5], [8]. One possible reason for this separation of language from content is that in many EFL contexts, there are few educators who are simultaneously familiar with the use of digital technology and effective pedagogy for literacy instruction. This points to the need to integrate instructional strategies with CALT in the context of tertiary-level EFL so that students can effectively navigate literacy activities. As such, this short paper is motivated by addressing the following research question: How can CALT in tertiary-level EFL contexts be enhanced, placing a dual focus on both languages? In particular, this short paper discusses how to improve CALT by integrating systemic functional linguistics (which is detailed in section 2), and provides recommended practices for tertiary-level EFL teachers in this regard.

\section{Integrating language and content through systemic functional linguistics}

Systemic functional linguistics (SFL) is a suitable tool for complementing CALT because it emphasizes and explains the close relationship between language and meaning (i.e., the content of a discourse, as seen in relevant studies [10], [11],[12], [13], albeit not in the field of CALT).

By emphasizing the interaction between content and language resources, SFL points out that the content of any discourse has three meanings: ideational meaning (the meaning that is almost tantamount to the overarching main idea of a discourse, reified by the main ideas as well as the logical relationships between the individual sentences); interpersonal meaning (the evaluative stances of a discourse); and textual meaning (the fluency of a discourse as reified by the sentences or paragraphs)[13]. These three meanings may differ depending on the choice of linguistic resources in relation to the contextual variables: field (what a discourse is about), tenor (whom a discourse targets), and mode (how a discourse is communicated) [14].

In addition, SFL provides names for linguistic resources that participate in realizing meanings [14]. This means that for the construction or deconstruction of a discourse, the conventional use of linguistic resources for realizing the meanings of a discourse in 
a particular context can be identified [11]. When they understand this level of relationship, language students will be able to effectively engage in literacy activities by using names to identify and analyze linguistic resources that realize meanings in discourses (e.g., reading and writing) while constructing conventionally recognized or innovative texts on their own (see Table 1 for some names of linguistic resources at each level of meaning) [11].It has to be acknowledged, however, that SFL entails more than has been mentioned above and in Table 1. Its use in the school setting can be simplified, as the purpose of using SFL is to provide students with sufficient knowledge of linguistics, assisting them in effectively meeting the demands of school literacy [15].

Table 1. The triadic relationship between meaning, linguistic resources, and names

\begin{tabular}{|l|c|l|}
\hline \multicolumn{1}{|c|}{ Literacy activities } & Content & Key names or labels for linguistic resources [13], [14], [16] \\
\hline \multirow{2}{*}{$\begin{array}{l}\text { Ideational } \\
\text { meaning } \\
\text { deconstruction of } \\
\text { discourses: } \\
\text { text reading, } \\
\text { composing writing, } \\
\text { spoken discourse, etc. }\end{array}$} & $\begin{array}{l}\text { Participant: Nouns/noun phrases } \\
\text { Process: Verbs/verb phrases } \\
\text { Circumstance: Prepositions/prepositional phrases } \\
\text { Logical connectors: inter-sentential conjunction words } \\
\text { Logical fallacies: overstatement, false dichotomy, etc. }\end{array}$ \\
\cline { 2 - 3 } & Interpersonal \\
meaning & $\begin{array}{l}\text { Subject: Nouns/noun phrases } \\
\text { Voice: Passive/active voice } \\
\text { Attitude: Adjectives/adjective phrases } \\
\text { Graduation: Adjectives/adverbs } \\
\text { Engagement: Lexical expression of modality (e.g., modal } \\
\text { verbs) and expression of the source of information (person }+ \\
\text { saying verbs) }\end{array}$ \\
\cline { 2 - 4 } & Textual meaning & $\begin{array}{l}\text { Theme: The starting point of a sentence } \\
\text { Rheme: The parts other than the theme of a sentence } \\
\text { Cohesive devices: Conjunctions, } \\
\text { synonyms, antonyms, etc. }\end{array}$ \\
\hline
\end{tabular}

As shown in Table 1, the repertoire of names for ideational meaning includes participant, process, and logical connectors, which illustrate the composition of ideational meaning. When interacting with discourse construction (e.g., writing) or deconstruction (e.g., reading), students can focus on how individual discourses present their ideational meaning by focusing on the relationship between the ideational meaning, lexical resources, and the aforementioned names [13]. In so doing, they can understand or evaluate the ways in which authors of a discourse present their meanings [13]. They can thus produce their own meaning in a similar but non-prescriptive way [13]. Taking science texts for example, the label participant can help the students and teacher notice that nominalization (nouns or noun phrases derived from verbal phrases) or inanimate nouns /noun phrases frequently occur in this type of text to present compact ideas [11]. These ideas are also often logically connected through logical connectors (e.g., because) [11]. In other words, this label can help students to understand the interaction between language and meaning construction, without prescribing rules. Teachers can explain the relationship between the ideational meaning and its contextual variable field to further help students understand this mechanism [11]. This would illustrate to students that choices of participants for a particular ideational meaning are a reflection of the field [13]. For example, in a science context where the meaning is related to a scientific topic, the text will consist of logically related, compact, and precise ideas [13]. 
On the other hand, teachers could compare science texts with causal conversations that have more frequent use of pronouns to construct ideational meaning, with few logical connectors [11]. With the focus on names in relation to the configuration of ideational meaning, students will have an opportunity to effectively understand diverse types of texts and, in turn, create their own with the knowledge that they have gained [11].

SFL also has its own toolkit of names related to linguistic resources that realize interpersonal meaning: a meaning pertaining to how the author of a discourse interacts with his/her audience. Here, important names include voice, attitude, engagement, and graduation [11],[13], [14], [16]. Voice (passive or active) can help show whether the subject of a sentence is presented to readers explicitly or implicitly, depending on the intention of the author of the discourse [11]. In some discourses, such as science texts, the passive voice is frequently used to avoid the use of the subject (which may be the researcher or even unknown) and to show objectivity [11]. Attitude reveals the lexicalgrammatical relationship with regard to the discourse composers' or participants' attitudes that are intended to be conveyed to the audience [13], [16]. This name can help students understand the role of adjectives (along with adverbs or adverb phrases) in realizing interpersonal meaning [13]. In informative texts, this name can help reveal that the explicit use of adjectives or adjective phrases in conveying attitudes is avoided [11]. The label Engagement reveals how linguistic resources are used to present information certainty or sources of information. This includes modal verbs and the collocation of the subject and reporting verbs (e.g., say, suggest, or assert), and concessive words (e.g., admittedly, while) [13], [16]. This is very prominent in both spoken and written texts, where information certainty is demanded to ensure the clarity and reliability of communication [11]. Graduation helps identify the linguistic resources used to affect the semantic load (e.g., how (in)effective an event is, or how good/bad a person is) of the information intended to be conveyed to the audience [13],[16]. The related linguistic resources include adverbs (e.g., frequently, typically) or adjectives (e.g., true), which are used to convey the strength of the evaluative stances embedded in the information conveyed to the audience [13], [16]. Taking this line of thought one step further, by connecting the names, interpersonal meaning, and the tenor of the contextual variable (the relationship between the discourse composer and the audience), teachers can assist their students in further understanding the different patterns of linguistic resources participating in different discourses (e.g., argumentative discourse, expository discourse, or daily spoken discourse), thus helping them effectively construct or deconstruct content [11], [13].

At the level of textual meaning, cohesive devices and theme patterns can help reveal how messages unfold in different modes [14]. The use of names as cohesive devices can help reveal the roles of lexical resources (e.g., synonyms, antonyms, hypernyms, and repetitive use of the same words) and grammatical resources (i.e., conjunction words). Theme patterns refer to the arrangement of sentence-level information; information at the beginning forms the theme and the remainder of the sentence forms the rheme [14]. The mystery of inter-sentence or paragraph-level flow of information across diverse modes of discourse can be revealed using these names [11]. For example, 
students can be guided to see that the parts of spoken discourses may be causally connected without the frequent use of conjunctions or regular theme patterns [11]. However, in the written mode, cohesive devices and theme patterns play a vital role in creating coherent discourses, regardless of genre [13]. For example, with the use of theme patterns, students are able to see that information may be connected through the same theme across the text or that sentences may be linearly connected to each other using the rheme of the preceding sentence as the theme.

\section{Integrating language and content through systemic functional linguistics}

As previously mentioned, SFL seems to be a good pedagogical tool for helping tertiary-level EFL students understand the relationship between language and content. Given that this is not taught in CALT, it would be beneficial to combine the two (CALT and SFL), as this would meet the demand of effectively engaging tertiary-level EFL students in literacy activities while leveraging the technological functions of CALT to galvanize their interest in learning. This section provides some suggestions as to how tertiary-level EFL teachers can navigate the affordances of both CALT and SFL.

\subsection{Cementing SFL with CALT inside and outside the class}

As stated in the previous section on SFL, SFL can be used to realize the curricular purpose of effectively teaching literacy in CALT, as illustrated by SFL's usefulness and its empirical use in non-CALT classrooms. It can be assumed that the integration of the technological uses (see Table 2, column 2) of CALT with SFL (Table 1, column 3) can further improve English language teaching. Thus, this section discusses the pedagogical connection between CALT and SFL with regard to EFL teaching.

Informed by the construct of ideational meaning and the contextual variable field, tertiary-level EFL teachers can help their students understand the relationship between ideational meaning and field by first focusing on linguistic resources in discourses during CALT (see also the previous section on SFL) [18]. We can consider the interactive function of CALT as an example. When unpacking the meaning or general idea (i.e., ideational meaning) of a text, students and teachers (including course tutors) can opt to interact with each other on the web-based platform, especially in a context where there is a heavy course load to cover or where intensive face-to-face interaction is impossible [3], [18]. On the web, when teachers try to engage their students in understanding the meaning of texts, they can remind their students to focus on whether the texts being read or written stay with the topic or whether the ideational meaning of a paragraph or a whole text is realized through topic-related linguistic resources [13],[18]. This can be especially achieved, for example, through the label participant, to help the students identify the type of noun or noun phrase in use, and through the label process, to help the students identify the verb or verb phrase in use [11], [13], [18]. Students can also be guided in understanding logical relationships as another part of ideational meaning, 
evaluating whether logical fallacies have been committed [11], [14],[18]. Similar practices can also be arranged between peers on the web, promoting their mutual assistance when teacher-guided instruction is over [3]. Apart from the interactive exercises, multimodal technological resources, such as video-based lectures on ideational meaning, can be sent to the students to help them preview or further understand the ideational meaning, and this can be enhanced by assignments based on online resources (e.g., students can be asked to analyze sample texts sourced online or to finish app-based learning tasks) [4], [5], [6]. Through this practice, students are expected to engage effectively in literacy activities at the level of ideational meaning [18].

Table 2. Implementing SFL and CALT: Tenets and practices

\begin{tabular}{|c|c|c|c|}
\hline & $\begin{array}{l}\text { Key tenets of technological } \\
\text { functions }\end{array}$ & Key tenets of SFL & $\begin{array}{l}\text { Key tents of integrated } \\
\text { CALT-SFL practices }\end{array}$ \\
\hline $\begin{array}{l}\text { Discourse } \\
\text { de/construc- } \\
\text { tion }\end{array}$ & $\begin{array}{l}\text { Technological functions (includ- } \\
\text { ing the use of audio-visual re- } \\
\text { sources, virtual game-based } \\
\text { learning, apps, and web-based } \\
\text { collaborative forms [5], [6], [7], } \\
\text { [8], [17] serve to: } \\
\text { engage students. } \\
\text { help students preview classroom } \\
\text { instruction. } \\
\text { facilitate teacher-student interac- } \\
\text { tions on the digital platform. } \\
\text { instantly provide digital feed- } \\
\text { back or assessment to enhance } \\
\text { students' learning. } \\
\text { supplement the students' learn- } \\
\text { ing obtained in the classroom. }\end{array}$ & $\begin{array}{l}\text { Make literacy visible by utiliz- } \\
\text { ing linguistic resources as a } \\
\text { gateway [11]. } \\
\text { Sensitize students to the rela- } \\
\text { tionship between language re- } \\
\text { sources and meanings while } \\
\text { guiding them in connecting } \\
\text { such relationships to the con- } \\
\text { text of discourses (e.g., read- } \\
\text { ing texts, dialogues) [11], [13]. } \\
\text { Engage students in independ- } \\
\text { ent navigation of discursive } \\
\text { activities [14]. }\end{array}$ & $\begin{array}{l}\text { Harness the function of } \\
\text { technological affordances } \\
\text { through their technologi- } \\
\text { cal use (see the second } \\
\text { column of this table) } \\
\text { [5],[6],[7],[8], [17]. } \\
\text { Support students' effec- } \\
\text { tive engagement in liter- } \\
\text { acy activities (see the } \\
\text { third column of this table) } \\
{[11] .}\end{array}$ \\
\hline
\end{tabular}

Students can also be guided to understand or construct interpersonal meaning by focusing on the relationships between tenor, interpersonal meaning, and linguistic resources (see also the previous section on SFL) in CALT [18]. In the following, we consider the technological function (i.e., the use of multimodal resources) of activating students' interests as an example. In a speaking classroom, teachers can share film clips or trailers with the students, guiding them in unpacking interpersonal meaning through relevant labels (e.g., engagement, attitude, voice), and in turn asking them to accordingly orally express their opinion or stance on the topic at the level of interpersonal meaning (see also section 2 on SFL) [18]. Similarly, CALT can first help students become familiar with this knowledge dimension through the use of multimodal resources (e.g., audio-visual resources) [14]. For example, through recorded lectures, students can learn the use of external voices in either arguing for or against a point in the literature review with the label engagement [18]. With the same label, students can also identify the use of a modulated tone, such as through modal verbs or the choices of verbs, in either weakening or strengthening the tone. Teachers can then provide digital feedback (comments on the students' writing provided on a Microsoft Word document or through web-based dialogues), further enhancing their students' knowledge of interpersonal meaning in relation to linguistic resources and labels [2], [3], [18]. In this way, it is 
hoped that students can be comprehensively guided in using interpersonal labels to critically construct or deconstruct discourses [18].

Teachers can help their students understand textual mechanisms in written and spoken discourses while navigating the technological affordances of CALT by focusing on textual meaning (see also section 2 on SFL). For example, students can be sent webbased resources (e.g., massive open online courses or other resources) as pre-class learning assignments to help them understand the relationship between themes and cohesive ties, on the one hand, and textual meaning, on the other [4], [6], [18]. In class, the students and the teacher can engage in joint activities using the labels, theme and cohesive devices, to unpack or construct textual meanings in diverse discourses [13]. After class, the teachers can send their students some app- or web-based practice exercises that can further help enhance their students' knowledge of these dimensions before they become proficient and learn to regulate the dimensions on their own [7], [18].

In summary, CALT and SFL are equally valuable, as their integration can better help tertiary-level EFL students become well rounded, transforming them into independent learners and making them effectively interact with literacy activities.

\subsection{Teachers' efforts in the process of implementing synergized teaching}

Tertiary-level EFL teachers also need to be dynamic in their teaching in the implementation of the aforementioned CALT framework. Teachers are required to assist students in diverse ways since students in local classrooms may have varied needs [19]. This means that, while following the framework provided above, tertiary-level EFL teachers need to make room for adaptions based on their students' needs.

One way of doing this is for teachers to listen to their students' voices [19]: their students' perceptions of and/or experiences with their course learning. Listening to their students' voices during their learning and understanding what their students are saying can provide teachers with first-hand information on teaching [20], such as the effects or effectiveness of the simultaneous implementation of SFL and CALT. Teachers can hear their students' voices through diverse channels, such as by interviewing them (e.g., asking them questions about their willingness to use technology or their level of engagement in such), asking them to provide reflections, or conducting surveys of students [21]. It is recommended that the students' voices be tracked within short intervals (e.g., weekly) across the semester so that teachers will instantly know how their learning is proceeding and can make adaptions if necessary [21]. Of course, teachers do not need to blindly listen to all their students' voices [20]. Indeed, there can be no effective teaching without listening or attending to the student's reactions or voices, but teachers can critically evaluate what their students are saying and change their teaching accordingly only if deemed necessary [20].

Teachers can also analyze their students' work to evaluate their students' responses [22], such as their interaction with SFL and CALT. For example, from their students' analytic work, teachers can evaluate the effectiveness of their students' analysis of text, such as their mastery of interpersonal meaning (including relevant names) in deconstructing reading texts. Teachers can also evaluate how their students use the 
knowledge they have acquired to construct their own writing, such as how effectively they can use cohesive devices to organize information [14].

Based on their students' voices and works, teachers can either choose to continue with their current teaching style or adapt their teaching (including both the technological and instructional dimensions) [21]. Generally, teachers can choose to maintain or adapt their teaching based on the progress of the majority of their students. This does not mean, however, that the voices of the students who form the minority should be deliberately ignored [20]. For example, in a language classroom where most of the students have a good knowledge of grammar, the teacher may focus more on the interaction between linguistic resources and content while harnessing CALT's technological functions (e.g., the use of apps and online materials to facilitate learning), but some students in the same classroom may expect additional instruction on grammar. To meet their students' idiosyncratic needs, teachers can provide the concerned students with after-class assistance [23]. Indeed, with regard to the technological dimension, some students may take more time to become accustomed to its use compared with textbookbased teaching [24].

More importantly, adaption to such a new integrated framework may be emotionally challenging for both the teacher and the students, as it means additional learning and teaching [25], [26]. In this case, both the teachers' and students' emotions should be attended to [25], [26]. Teachers need to play a mediating role in different ways for students, gradually improving their development and boosting their confidence to prevent them from becoming frustrated with their learning [27]. Students' negative emotions may hamper their further progress [27]. In contrast, students' positive emotions may help them to better engage in learning [27]. Implementing the new and integrated coursework means much more work for teachers, especially in terms of their workload and meeting their students' individual needs [26]. They, too, need to regulate their emotions [26], such as by seeking assistance from their colleagues or availing themselves of online assistance.

\section{Conclusions and future research}

This paper argues for the value of integrating SFL with CALT in the process of undertaking tertiary-level EFL teaching. In addition to focusing on the importance of leveraging CALT, this paper also highlights the importance of SFL in enhancing CALT-based EFL teaching by unpacking the link between linguistic resources and content and enabling students to use linguistic resources as a gateway to construct and deconstruct the content of a discourse. This paper also provides suggestions to teachers on how to integrate computer-based technology and SFL-enacting literacy instruction and how to improve the use of these two by attending to their students' voices and to their own emotions as teachers.

Future studies can address the following matters through empirical studies. First, given its importance, the traditional use of CALT should be revamped because it does not offer effective literacy instruction in EFL contexts. Future research can investigate the impact of the balanced use of CALT and SFL-based literacy instruction on tertiary- 
level EFL students' language learning. Second, future studies can explore whether teachers can be provided with more in-depth training in CALT in pre- and in-service training programs, along with effective pedagogy (e.g., SFL-based literacy instruction). In other words, future studies can explore making CALT design and innovation (e.g., the addition of SFL-based literacy instruction in CALT) a pre- or in-service training initiative and the impact of this on teachers' subsequent teaching.

\section{$5 \quad$ References}

[1] Davies, G. (2006). "Language Education, Computer-Assisted," Encyclopedia of Language \& Linguistics, pp. 460-470.

[2] Sinclair, K. J., Renshaw, C. E. and Taylor, H. A. (2004). "Improving computer-assisted instruction in teaching higher-order skills," Computers \& Education, vol. 42, no. 2, pp. 169180. https://doi.org/10.1016/s0360-1315(03)00070-8

[3] Zeng, G. and Takatsuka, S. (2009). "Text-based peer-peer collaborative dialogue in a computer-mediated learning environment in the EFL context," System, vol. 37, no. 3, pp. 434446, Sep. https://doi.org/10.1016/j.system.2009.01.003

[4] Xu, Z., Banerjee, M., Ramirez, G, Zhu, G. and. Wijekumar, K. 92018). "The effectiveness of educational technology applications on adult English language learners' writing quality: A meta-analysis," Computer Assisted Language Learning, vol. 32, no. 1-2, pp. 132-162. https://doi.org/10.1080/09588221.2018.1501069

[5] Angraeni, L., Chuzaimah, C. and Nasir, F. (2019). "Investigating EFL students' perception of English vocabulary acquisition through online gaming," ELT Worldwide: Journal of English Language Teaching, vol. 6, no. 2, p. 162-170. https://doi.org/10.26858/eltww.v6i2. $\underline{13328}$

[6] Alwehaibi, H. O. (2015). "The impact of using Youtube in EFL classroom on enhancing EFL students' content learning," Journal of College Teaching \& Learning (TLC), vol.12, no.2, pp.121-126. https://doi.org/10.19030/tlc.v12i2.9182

[7] Nami, F., Marandi, S. S. and Sotoudehnama, E. (2018). "Interaction in a discussion list: An exploration of cognitive, social, and teaching presence in teachers' online collaborations," ReCALL, vol. 30, no. 3, pp. 375-398. https://doi.org/10.1017/s0958344017000349

[8] Bataineh, R. F. and Mayyas M. B. (2017). "The utility of blended learning in EFL reading and grammar: A case for Moodle," Teaching English with Technology, vol.17, no. 3, pp. 35-49.

[9] Shang, H. F. and Chen, Y. Y. (2018). "The impact of online autonomous learning on EFL students' reading skills," International Journal on E-Learning, vol. 17, no. 2, pp. 227-249.

[10] Coffin, C. and Donohue, J. P. (2012). "Academic literacies and systemic functional linguistics: How do they relate?” Journal of English for Academic Purposes, vol. 11, no. 1, pp. 6475. https://doi.org/10.1016/j.jeap.2011.11.004

[11] Schleppegrell, M. J. (2004). The language of schooling: A functional linguistics perspective, Mahwah, NJ: Erlbaum.

[12] Santiago Schwarz V., and Hamman-Ortiz, L. (2020). "Systemic functional linguistics, teacher education, and writing outcomes for U.S. elementary English learners: A review of the literature," Journal of Second Language Writing, vol. 49. https://doi.org/10.1016/ j.jslw.2020.100727

[13] Rose, D. and Martin, J. R. (2012). Learning to write, reading to learn: Genre, knowledge and pedagogy in the Sydney School, London: Equinox. 
Paper-Revisiting Computer-Assisted Language Teaching: What Else Do Tertiary-Level EFL Teachers...

[14] Halliday, M. and Matthiessen, C.M. (2014). An introduction to functional grammar, Routledge.

[15] Macken-Horarik, M. (2012). "Why School English Needs a 'Good Enough' Grammatics (and Not More Grammar)," Changing English, vol. 19, no. 2, pp. 179-194. https://doi .org/10.1080/1358684x.2012.680760

[16] Martin, J. R. and White. P. R. R. (2005). The Language of Evaluation: Appraisal in English. New York: Palgrave Macmillan.

[17] Tai, T.-Y., Chen, H. H.-J and Todd, G. (2020). "The impact of a virtual reality app on adolescent EFL learners' vocabulary learning," Computer Assisted Language Learning, pp. 1-26. https://doi.org/10.1080/09588221.2020.1752735

[18] Zhang, X. (2018). "Connecting OER with mandatory textbooks in an EFL classroom: A language theory-based material adoption," The International Review of Research in Open and Distributed Learning, vol. 19, no. 2. https://doi.org/10.19173/irrodl.v19i2.3479

[19] Canning, J. (2016). "Conceptualising student voice in UK higher education: Four theoretical lenses," Teaching in Higher Education, vol. 22, no. 5, pp. 519-531. https://doi.org/10.1080/ 13562517.2016 .1273207

[20] Pearce, T. C. and Wood, B. E. (2016). "Education for transformation: An evaluative framework to guide student voice work in schools," Critical Studies in Education, vol. 60, no. 1, pp. 113-130. https://doi.org/10.1080/17508487.2016.1219959

[21] Johnson, B. and Christensen, L. (2012). Educational Research: Quantitative, qualitative, and mixed approaches, CA: Sage.

[22] Ayoobiyan, H. and Rashidi, N. (2021). "Can reflective teaching promote resilience among Iranian EFL teachers? A mixed-method design,” Reflective Practice, pp. 1-13. https://doi. org/10.1080/14623943.2021.1873758

[23] Kuryan, M. and Voronina, E. (2020). "Out-of-class communication: are students and faculty interested and engaged? (A study at a Russian university)," Educational Research for Policy and Practice, Sep. https://doi.org/10.1007/s10671-020-09277-3

[24] Osorno González, J. A. and Lopera Medina, S. A. (2012). "Interaction in an EFL reading comprehension distance web-based course," Íkala, vol.17, no. 1, pp.45-59.

[25] Xing, W., Tang, H. and Pei, B. (2019). "Beyond positive and negative emotions: Looking into the role of achievement emotions in discussion forums of MOOCs," The Internet and Higher Education, vol. 43. https://doi.org/10.1016/j.iheduc.2019.100690

[26] Burić, I. and Macuka, I. (2017). "Self-efficacy, emotions and work engagement among teachers: A two wave cross-lagged analysis," Journal of Happiness Studies, vol. 19, no. 7, pp. 1917-1933. https://doi.org/10.1007/s10902-017-9903-9

Lei, H., Cui, Y. and Chiu, M. M. (2018). "The relationship between teacher support and students' academic emotions: A meta-analysis," Frontiers in Psychology, vol.8. https://doi. org/10.3389/fpsyg.2017.02288

\section{Authors}

Xiaodong Zhang is an associate professor at School of English and International Studies, Beijing Foreign Studies University, China.

Article submitted 2021-02-06. Resubmitted 2021-05-17. Final acceptance 2021-05-18. Final version published as submitted by the authors. 